\title{
Genome-wide gene-air pollution interaction analysis of lung function in 300,000 individuals
}

\author{
Carl A. Melbourne ${ }^{1}$, A. Mesut Erzurumluoglu ${ }^{2}$, Nick Shrine ${ }^{1}$, Jing Chen ${ }^{1}$, Martin D. Tobin ${ }^{1,3}$, Anna \\ Hansell ${ }^{4}$, Louise V. Wain ${ }^{1,3}$ \\ ${ }^{1}$ Department of Health Sciences, University of Leicester, Leicester, UK \\ ${ }^{2}$ MRC Epidemiology Unit, University of Cambridge, Cambridge, UK \\ ${ }^{3}$ National Institute for Health Research, Leicester Respiratory Biomedical Research Centre, Glenfield \\ Hospital, Leicester, UK \\ ${ }^{4}$ Centre for Environmental Health and Sustainability, University of Leicester, Leicester, UK
}

\begin{abstract}
Impaired lung function is predictive of mortality and is a key component in the diagnosis of chronic obstructive pulmonary disease. Lung function has a strong genetic component but is also affected by environmental factors such as increased exposure to air pollution. How genetic factors and air pollution interact to affect lung function is however less understood.
\end{abstract}

We conducted a genome-wide gene-air pollution interaction analysis of spirometry measures with three measures of air pollution at home address: particulate matter $\left(\mathrm{PM}_{2.5} \& \mathrm{PM}_{10}\right)$ and nitrogen dioxide $\left(\mathrm{NO}_{2}\right)$, in approximately 300,000 unrelated European individuals from UK Biobank. We explored air pollution interactions with previously identified lung function signals and determined their combined interaction effect using a polygenic risk score (PRS).

We identified seven genome-wide interaction signals $\left(P<5 \times 10^{-8}\right)$, and a further ten suggestive interaction signals $\left(P<5 \times 10^{-7}\right)$. We found statistical evidence of interaction with $\mathrm{PM}_{2.5}$ for previous lung function signal, rs 10841302 , near $A E B P 2$, suggesting increased susceptibility of $\mathrm{FEV}_{1} / \mathrm{FVC}$ to $\mathrm{PM}_{2.5}$, as copies of the $\mathrm{G}$ allele increased (interaction beta: -0.073 percentage points, $95 \% \mathrm{Cl}:-0.105,-0.041)$. There was no observed interaction between air pollutants and the weighted genetic risk score.

We carried out the largest genome-wide gene-air pollution interaction study of lung function and identified effects of clinically relevant size and significance. We observed up to $440 \mathrm{ml}$ lower lung function for certain genotypes associated with mean levels of outdoor air pollution at baseline, which is approximately equivalent to nine years of normal loss of lung function.

\section{Introduction}

Impaired lung function is predictive of mortality and is a key component in the diagnosis of chronic obstructive pulmonary disease (COPD). Smoking is the biggest risk factor for COPD, which is thought to have caused as many as 2.9 million deaths worldwide in 2016 (1) although other sources of indoor air pollution are also associated with COPD risk $(2,3)$. Furthermore, increased exposure to air pollution is associated with lower lung function (4).

NOTE: This preprint reports new research that has not been certified by peer review and should not be used to guide clinical practice. 
medRxiv preprint doi: https://doi.org/10.1101/2021.06.03.21256376; this version posted June 7, 2021. The copyright holder for this preprint

(which was not certified by peer review) is the author/funder, who has granted medRxiv a license to display the preprint in perpetuity.

It is made available under a CC-BY 4.0 International license .

Lung function and COPD risk is also influenced by genetic factors and we and others have discovered over 300 genetic association signals for COPD risk and/or lung function measures $(5,6)$. Combining these signals into a single polygenic risk score, we have shown that individuals in the highest decile of genetic risk have an almost 5 -fold increased risk of COPD compared to those in the lowest decile. However, collectively, these variants only explain up to around $13 \%$ of the heritability of lung function.

We hypothesised that there could be interactions between genetic variants and air pollution measures which affect COPD risk and lung function. Detection of such effects could enable identification of high-risk subgroups of the population and provide new biological insight into the mechanisms whereby air pollution affects respiratory health.

To test this hypothesis, we carried out the largest genome-wide gene-air pollution interaction study of lung function in 300,000 individuals from UK Biobank, using particulate matter (PM) and nitrogen dioxide $\left(\mathrm{NO}_{2}\right)$ concentrations as measures of air pollution exposure.

\section{Methods and Materials}

\section{Selection of individuals with lung function data}

We selected unrelated European individuals from UK Biobank as previously described (6). In summary, we selected individuals that had complete lung function data and passed our previously outlined quality control filters for forced expiratory volume in 1 second $\left(\mathrm{FEV}_{1}\right)$, forced vital capacity $(F V C)$ and the ratio $\left(F E V_{1} / F V C\right)$. From this we then selected a subsample of unrelated individuals of genetically determined European ancestry (KING kinship coefficient $<0.0884$ corresponding to below $2^{\text {nd }}$ degree kinship (7)). All individuals had complete data for sex, age, height and ever smoking status (ever vs never).

\section{Air pollution data}

Air pollution concentrations at place of residence of UK Biobank participants at recruitment were estimated using European Study of Cohorts and Air Pollution Effects (ESCAPE) land use regression models $(8,9)$. In these analyses, we explored associations with fine particles with average diameter < $2.5 \mu \mathrm{m}\left(\mathrm{PM}_{2.5}\right)$, particulate matter with average aerodynamic diameter $<10 \mu \mathrm{m}\left(\mathrm{PM}_{10}\right)$ and annual average concentrations of nitrogen dioxide $\left(\mathrm{NO}_{2}\right)$.

For the particulate measures, models were not robust more than $400 \mathrm{~km}$ from Greater London, so analyses did not include participants from northern England and Scotland. ESCAPE $\mathrm{NO}_{2}$ variables were available UK-wide.

\section{Genome-wide interaction analysis}

$\mathrm{FEV}_{1}, \mathrm{FVC}$ and $\mathrm{FEV}_{1} / \mathrm{FVC}$ were adjusted for sex, age, age ${ }^{2}$, height and ever smoking. Residuals were then inverse normal transformed. Air pollution measures $\mathrm{PM}_{2.5}$ and $\mathrm{PM}_{10}$ were transformed into standard z-scores to avoid collinearity issues between the air pollution and interaction terms 
medRxiv preprint doi: https://doi.org/10.1101/2021.06.03.21256376; this version posted June 7, 2021. The copyright holder for this preprint (which was not certified by peer review) is the author/funder, who has granted medRxiv a license to display the preprint in perpetuity.

It is made available under a CC-BY 4.0 International license .

(observed due to small measurement variances). Air pollution measure $\mathrm{NO}_{2}$ was analysed untransformed.

Individuals were genotyped using the Affymetrix Axiom UK BiLEVE and Affymetrix Axiom UK Biobank arrays (10) with imputation undertaken using the Haplotype Reference Consortium (HRC) (11)and combined UK10K +1000 genomes (12) reference panels. Multiallelic variants were removed and variants imputed with low confidence were excluded (imputation quality $r^{2}<0.5$ for all SNPs and $r^{2}<$ 0.8 for rare SNPs with minor allele frequency $(\mathrm{MAF})<1 \%)$. Variants with MAF less than $0.5 \%$ were removed.

Each transformed lung function trait was used as the outcome in a multiple regression model which included the first 15 principal component terms for ancestry, genotyping array, SNP term (using an additive genetic model), air pollution variable and an interaction term for the interaction between SNP and air pollution:

$$
\text { Phenotype }_{i}=\beta_{0}+\beta_{1} G_{i}+\beta_{2} A_{i}+\beta_{3} G_{i} A_{i}+P C_{1 i} \ldots P C_{15 i}+\text { Array }_{i}+\varepsilon_{i} \quad \text { (Equation 1) }
$$

where $G_{i}$ is the genotype for individual $i, A_{i}$ is the air pollution value, $P C_{1 i} \ldots P C_{15 i}$ represent principal component values and Array $_{i}$ is the genotype array value (coded 0 and 1 for UK Biobank array and UK BiLEVE array respectively). The $\mathrm{p}$-value returned for the $\beta_{3}$ estimate corresponds to the interaction effect between SNP and air pollution value $\left(G_{i} A_{i}\right)$. Multiple regression was performed using PLINK2 (13).

\section{Signal selection and fine-mapping}

To define association signals and their sentinel variants, all variants were ranked by $p$-value and the SNP with the lowest $p$-value was selected as the first signal sentinel. All SNPs $+/-1$ megabase (Mb) either side of this first sentinel were then excluded and the process repeated for the next most significant SNP until all $2 \mathrm{Mb}$ regions containing a sentinel SNP with $P<5 \times 10^{-8}$ had been identified (genome-wide signals). The process was repeated to define a set of signals with sentinel SNPs at threshold of $P<5 \times 10^{-7}$ (suggestive signals). Conditional analysis was used to identify additional independent genome-wide and suggestive signals by including the sentinel interaction term in the model, re-analysing all SNPs within each $2 \mathrm{Mb}$ region and determining whether any SNPs remained below the pre-specified threshold. Region plots for each signal were created using LocusZoom (14).

To aid the interpretation of interaction effects for genome-wide significant interaction signals, we presented the association between lung function trait and air pollution variable stratified by genotype group. To do this, dosages were converted to direct genotype calls by rounding to the nearest genotype group.

Using a Bayesian method (15) we fine-mapped each signal to a credible set of SNPs (the set of SNPS 95\% likely to contain the causal SNP, under the assumption that the causal SNP was analysed).

Identification of putative causal genes 
medRxiv preprint doi: https://doi.org/10.1101/2021.06.03.21256376; this version posted June 7, 2021. The copyright holder for this preprint (which was not certified by peer review) is the author/funder, who has granted medRxiv a license to display the preprint in perpetuity. It is made available under a CC-BY 4.0 International license.

Credible set SNPs including the sentinel SNP were annotated using Annovar (16) to identify coding variants with a putative functional effect (for example, missense). To identify whether any of the signals were independently associated with gene expression, we searched the GTEx (17) and blood eQTLgen (18)eQTL catalogues. To identify a potential shared causal variant between the SNP-air pollution interaction signals and the eQTL gene expression signals, colocalisation was undertaken using COLOC (19) where full summary data was available in GTEx and eQTLgen databases (20). An observed probability $>0.8$ for a shared causal variant was used as the threshold to conclude colocalisation of SNP-air pollution and gene expression signals. We queried the sentinel SNPs in Open Target Genetics (21) for eQTL associations (which in addition to GTEx includes a further 14 consortia with eQTL expression association results) and to identify associations with protein expression ( $\mathrm{pQTL}$ ) and overlap with regions known to interact with gene promoters (promotor capture $\mathrm{HiC})$.

\section{Association with other phenotypes}

The SNP with the highest posterior probability for causality in each credible set was queried in PhenoScanner (22) and Open Targets Genetics (21) resources to identify shared associations with other phenotypes at a threshold of $P<1 \times 10^{-3}$.

\section{Functional enrichment}

To identify whether there was enrichment of SNP-air pollution interaction signals within regulatory regions of the genome (for example, DNase Hypersensitivity Sites) in specific cell or tissue types we used GARFIELD (23). The software determines whether signals are enriched for DNase I hypersensitive sites across 55 tissues (with an adjusted significant enrichment threshold for 540 effective annotations of $P<9.26 \times 10^{-5}$ ). We investigated the functional impact of SNPs (potential chromatin effects) which were highly probable to be the drivers of each signal (i.e. SNPs with posterior probability $>0.9$ in credible sets) using DeepSEA (24). To define a significant functional impact we used an E-value $<0.05$ (the proportion of 1000 Genomes SNPs predicted to have a higher magnitude for chromatin effect compared to the chosen SNP being investigated) and an absolute probability difference $>0.1$ between alternative and reference allele (the threshold defined for 'high confidence').

\section{Effects of Socio-Economic Status}

Socio-economic status (SES) of an individual is a plausible moderator of lung function, with observed modification of air pollution effects (4), however adjusting for SES in our analyses would have led to a reduction of approximately $13 \%$ in the discovery sample size due to missing data. We accounted for any effects of SES on genome-wide interaction signals in two ways. Firstly, we undertook a sensitivity analysis for the top signals adjusting for educational status and income status using a complete-case analysis (after inverse normalisation of lung function traits). Secondly, we present interaction effects for genome-wide signals across categorised groups for income and educational status to visualise any difference in effect (akin to a three-way interaction between SNP, air pollutant and education/income). Income status was categorised using the definition in UK Biobank of "less than $£ 18,000$ ", " $£ 18,000$ to $£ 30,999$ ", " $£ 31,000$ to $£ 51,999$ ", " $£ 52,000$ to 100,000 " and "Greater than 100,000". Educational status was dichotomised as "lower vocational qualification or less" vs "higher vocational qualification or more", grouping A-level (2), O-level (3), CSEs (4), and 
medRxiv preprint doi: https://doi.org/10.1101/2021.06.03.21256376; this version posted June 7, 2021. The copyright holder for this preprint (which was not certified by peer review) is the author/funder, who has granted medRxiv a license to display the preprint in perpetuity. It is made available under a CC-BY 4.0 International license.

"None of the above" (-7) under "low education", and College/University (1), NVQ (5) and Other professional qualifications (6) under "high education". Individuals who selected "Do not know" (-1), "Prefer not to answer" (-3) or have missing data were excluded from subsequent analyses.

\section{Previously reported lung function and COPD association signals}

We performed a look-up in the genome-wide gene-air pollution interaction analyses (for all three air pollution measures and all three lung function measures), for the 304 signals previously reported for association with lung function and COPD (279 lung function signals from Shrine et al. 2019 (6) and 25 signals from Sakornsakolpat et al. 2019 (5)). As these independent signals have $a$ priori evidence for association with lung function or COPD, we applied a Bonferroni corrected threshold for 304 tests to define a significant air pollution interaction effect $\left(P<1.6 \times 10^{-4}\right)$. As before, to aid interpretation of the interaction effect for any statistically significant signal, we present the association between lung function trait and air pollution stratified by genotype group.

\section{Weighted genetic risk score interaction analysis}

We used a weighted polygenic risk score (PRS) to explore whether the combined effect of previously reported lung function signals showed an interaction with air pollution measures (i.e. whether the phenotypic effects of the SNPs were modified by exposure to air pollution). Each individual's score was calculated using the effect sizes of the 279 SNPs reported in Shrine et al. 2019 (6) on FEV 1 /FVC (using the lung function reducing allele as the coded allele). Multiple regression was performed using the same model above, using the weighted polygenic risk score in place of the genotype. As all three lung function traits are correlated, interaction terms (i.e. wGRS $\times$ Air pollution measure) with $P<$ 0.05 were defined as statistically significant.

Antioxidant genes and their interaction with air pollution

Genetic variation within antioxidant genes may contribute to susceptibility of adverse effects of air pollution on respiratory health (25). We have provided look-ups for the most commonly evaluated antioxidant genes (for which a SNP was reported) and for SNPs evaluated in previous antioxidantgene-air pollution interaction studies, both of which are reviewed in Fuertes et al. (25). A Bonferroni adjusted threshold of $\mathrm{P}<3.85 \times 10^{-3}$ (for 13 variants) was used to determine statistical significance.

\section{Results}

\section{Genome-wide interaction analysis}

Genome-wide interaction analysis was undertaken in 277,597 European individuals from UK Biobank for air pollution variables $\mathrm{PM}_{10} / \mathrm{PM}_{2.5}$, (Supplementary table 1) and a total of 10,848,082 SNPs (Supplementary figure 1). For the $\mathrm{NO}_{2}$ analysis, there were 299,015 European individuals and 10,846,777 SNPs. Manhattan plots are presented in Figure 1 and QQ plots in supplementary figure 2. 


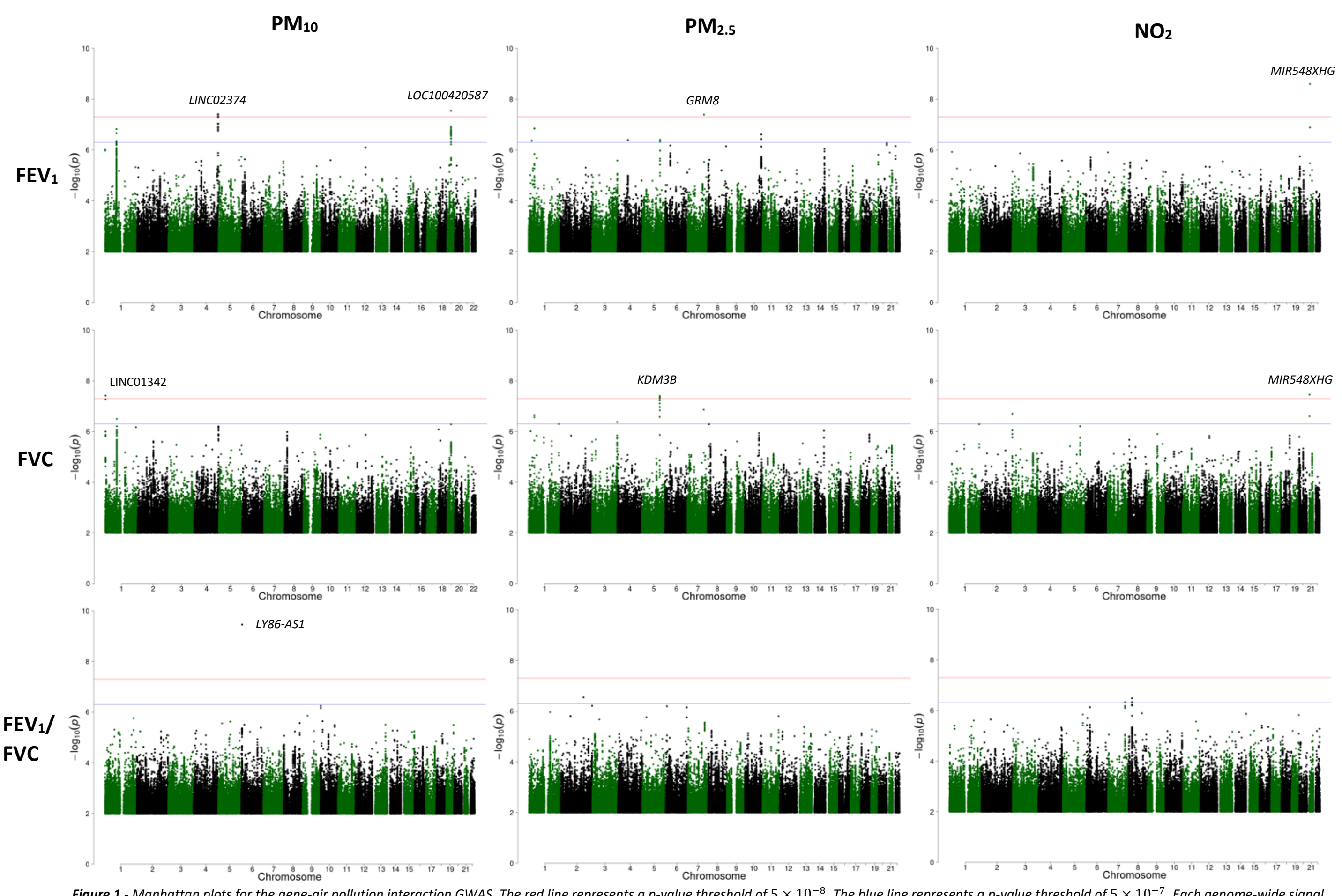

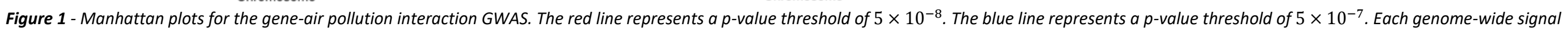
is annotated by nearest gene. 
medRxiv preprint doi: https://doi.org/10.1101/2021.06.03.21256376; this version posted June 7, 2021. The copyright holder for this preprint (which was not certified by peer review) is the author/funder, who has granted medRxiv a license to display the preprint in perpetuity.

It is made available under a CC-BY 4.0 International license .

We identified seven signals with an interaction effect reaching genome-wide statistical significance $\left(P<5 \times 10^{-8}\right)$ for at least one lung function trait and air pollution variable (Table 1,

Supplementary table 2 and Supplementary figure 3). Four signals were identified for an interaction with $\mathrm{PM}_{10}$. These included two for $\mathrm{FEV}_{1}$ (in 4q35.2 [near LINC02374] and in 19q12 [near LOC100420587]), one for FVC (in 1p36.33 [near LINC01342]) and one for FEV 1 /FVC (in 6p25.1 [in LY86-AS1]). Two signals were identified for an interaction with $\mathrm{PM}_{2.5}$; one for $\mathrm{FEV}_{1}$ (in $7 \mathrm{q} 31.33$ [near GRM8]) and one for FVC (in 5q31.2 [in KDM3B]. One signal was identified for air pollutant $\mathrm{NO}_{2}$ for both lung function traits $\mathrm{FEV}_{1}$ and FVC (in 21q21.1 [near MIR548XHG]). Of the seven identified SNPs, three were common (MAF $>5 \%)$ two were low frequency, $(1 \%<\mathrm{MAF}<5 \%)$ and two were rare (MAF $<1 \%)$. Conditional analysis did not identify any additional signals in each region.

To aid with the interpretation of statistically significant interaction effects, we have presented the association between air pollution and lung function stratified by genotype group (number of copies of coded allele) for each of the seven genome-wide interaction signals (Figure 2) and interaction plots of predicted lung function against air pollution for each genotype group (Supplementary figure 4). In some instances, statistically significant association between lung function and air pollutant is observed in all genotype groups. For others, the association only reaches statistical significance for certain genotype groups.

Signals were deemed suggestively statistically significant using the same signal selection procedure with a threshold of $5 \times 10^{-7}$ (Supplementary table 3 and Supplementary figure 5). Region plots after conditional analysis suggested only one signal per $2 \mathrm{Mb}$ region. Ten suggestive signals were identified that were independent of the seven genome-wide significant signals, all were either intergenic or mapped to the intronic region of the mapped gene. Eight were represented by common SNPs, and two by low frequency SNPs. 


\begin{tabular}{|c|c|c|c|c|c|c|c|c|c|c|c|c|c|}
\hline LF trait & AP & SNP & CHR & BP & Coded & $\begin{array}{l}\text { Non } \\
\text { Coded }\end{array}$ & CAF & INFO & BETA & SE & $\begin{array}{l}\text { LF effect (ml for } \\
\text { FEV }_{1}, F V C \text { or } \% \\
\text { points for } \\
\left.\text { FEV }_{1} / F V C\right)\end{array}$ & $\mathbf{P}$ & Locus \\
\hline FVC & $\mathrm{PM}_{10}$ & rs74048016 & 1 & 1068280 & C & G & 0.98 & 0.97 & -0.053 & 0.010 & -50.8 & $3.83 \times 10^{-8}$ & $\begin{array}{l}\text { C1orf159 (dist=16811), } \\
\text { LINC01342 (dist=4117) }\end{array}$ \\
\hline $\mathrm{FEV}_{1}$ & $\mathrm{PM}_{10}$ & rs28666788 & 4 & 188078645 & G & $A$ & 0.096 & 0.99 & -0.025 & 0.005 & -18.9 & $3.92 \times 10^{-8}$ & $\begin{array}{c}\text { FAT1 (dist=433635), LINC02374 } \\
\text { (dist=44495) }\end{array}$ \\
\hline FVC & $\mathrm{PM}_{2.5}$ & rs192415220 & 5 & 137726002 & C & $\mathrm{T}$ & 0.006 & 0.94 & -0.100 & 0.018 & -95.9 & $3.96 \times 10^{-8}$ & KDM3B \\
\hline $\mathrm{FEV}_{1} / \mathrm{FVC}$ & $\mathrm{PM}_{10}$ & rs137914543 & 6 & 6414006 & G & GTCTC & 0.06 & 0.83 & -0.038 & 0.006 & -0.24 & $3.55 \times 10^{-10}$ & LY86-AS1 \\
\hline $\mathrm{FEV}_{1}$ & $\mathrm{PM}_{2.5}$ & rs138235384 & 7 & 125969169 & C & $\mathrm{T}$ & 0.994 & 0.90 & -0.097 & 0.018 & -73.3 & $4.10 \times 10^{-8}$ & $\begin{array}{l}\text { LOC101928283 (dist=949794), } \\
\text { GRM8 (dist=109483) }\end{array}$ \\
\hline $\mathrm{FEV}_{1}$ & $\mathrm{PM}_{10}$ & rs762101031 & 19 & 29112275 & CAAT & C & 0.96 & 0.79 & -0.046 & 0.008 & -34.8 & $2.87 \times 10^{-8}$ & LOC100420587 \\
\hline $\mathrm{FEV}_{1}$ & \multirow{2}{*}{$\mathrm{NO}_{2}$} & \multirow{2}{*}{ rs2825255 } & \multirow{2}{*}{21} & \multirow{2}{*}{20362376} & \multirow{2}{*}{$\mathrm{T}$} & \multirow{2}{*}{ C } & \multirow{2}{*}{0.83} & \multirow{2}{*}{1.00} & -0.003 & 0.001 & -0.23 & $2.53 \times 10^{-9}$ & \multirow{2}{*}{$\begin{array}{l}\text { MIR548XHG (dist=230246), } \\
\text { LINC01683 (dist=903217) }\end{array}$} \\
\hline FVC & & & & & & & & & -0.003 & 0.001 & -0.29 & $3.52 \times 10^{-8}$ & \\
\hline
\end{tabular}

Table 1 - Seven identified genome-wide gene-air pollution interaction signals, $C A F=$ Coded Allele Frequency, INFO - imputation quality, AP = Air Pollutant, $L F=L$ Lung Function, $B P=B a s e$ Position. A negative BETA (interaction effect) suggests a more deleterious effect on lung function per unit increase of air pollutant as the coded allele increases. A positive BETA (interaction effect) suggests a more protective effect. Interaction effect is per unit increase in air pollutant $\mathrm{NO}_{2}\left(1 \mu \mathrm{g} / \mathrm{m}^{3}\right)$ and per standard deviation increase for air pollution variables $P M_{10}$ and $P M_{2.5}$ as the coded allele increases. Lung function effects are the product of the BETA value and the observed standard deviation of the lung function trait within the analysed sample. 

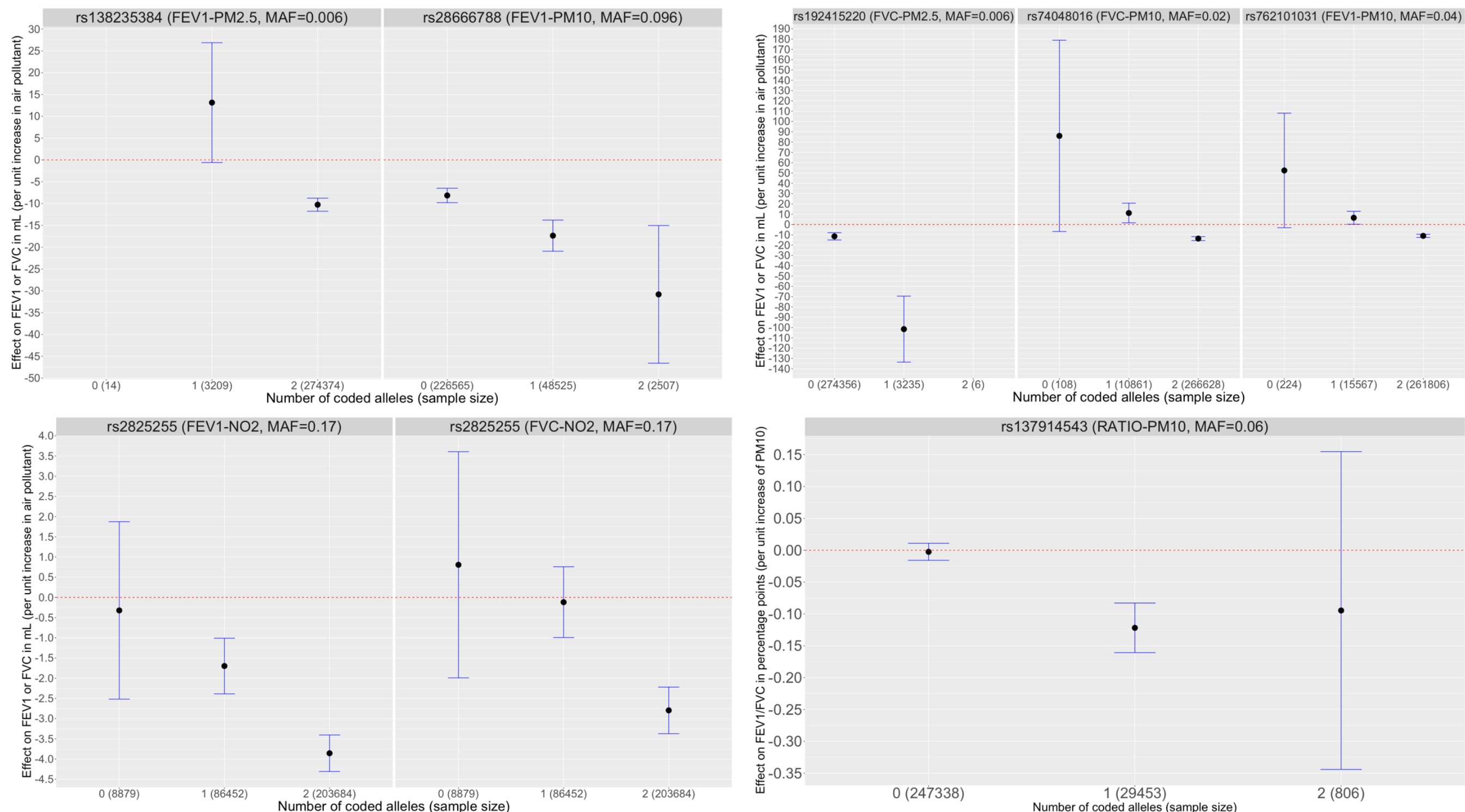

Figure 2 - Association between lung function trait and air pollutant (effect size and confidence intervals) for the seven genome-wide signals. Note: For SNPs rs138235384 and rs192415220 the effect size for 0 copies and 2 copies of the effect allele respectively are not presented due to the low minor allele frequency and small sample size. Effect sizes will not be exactly consistent with Table 1 due to rounding error when converting from dosage to direct genotypes. 
medRxiv preprint doi: https://doi.org/10.1101/2021.06.03.21256376; this version posted June 7, 2021. The copyright holder for this preprint (which was not certified by peer review) is the author/funder, who has granted medRxiv a license to display the preprint in perpetuity. It is made available under a CC-BY 4.0 International license .

\section{Credible sets and causal genes}

To determine a causal gene for each signal (both genome-wide and suggestively significant), we used Bayesian fine mapping to define the $95 \%$ credible set of causal SNPs (assuming the causal SNP was included in the analysis, Supplementary table 4) and investigated whether credible set and sentinel SNPs were associated with changes in gene expression in GTEx, Blood eQTL and Open Target Genetics databases (Supplementary table 5). Genome-wide significant signal, rs74048016, whose C allele had a larger deleterious effect on lung function as the measurement of $\mathrm{PM}_{10}$ increased, was associated with decreased expression of HES4 and increased expression of C1orf159 and RP11465 B22.3 in blood. The signals did not colocalise with the known gene expression signals in this region (using the eQTLgen database (20)). Credible set SNPs for suggestive signals rs769937512, rs111552599, rs139556451, rs200460259 and rs10082259 were associated in various tissues for genes AL445991.1, FRAS1, PNMA2/DPYSL, MUC4/MUC20 and UROD respectively (Supplementary table 5). These signals did not colocalise. There was no association with protein expression and no overlap with regions that had strong evidence for interaction with gene promoters.

\section{Association with other phenotypes}

Sentinel SNPs were queried in PhenoScanner and Open Targets Genetics resources (Supplementary table 6). Five signals were found to be associated with at least one trait at $P<1 \times 10^{-3}$, three genome-wide signals (rs28666788, rs192415220 and rs138235384) and two suggestive signals (rs10082259/rs6661026 and rs769937512). None of the associations reached genome-wide significance $\left(P<5 \times 10^{-8}\right)$. For the genome-wide signals rs28666788, rs192415220 and rs138235384 the strongest associations were with alcohol consumption, self-reported cervical polyps and sexual dysfunction respectively (at $<5 \times 10^{-6}$ ).

\section{Functional enrichment}

When looking for evidence of significant functional enrichment at DNase I hypersensitive sites (DHS) using GARFIELD, SNPs showing SNP-NO $\mathrm{N}_{2}$ interaction effects on lung function phenotype FVC were enriched in various tissues including fetal lung, using a threshold of $\boldsymbol{P}<\mathbf{5} \times \mathbf{1 0}^{-\mathbf{5}}$ to select contributing SNPs (Supplementary figure 6). No significant functional enrichment was observed when considering genome-wide statistically significant SNPs only $\left(\boldsymbol{P}<\mathbf{5} \times \mathbf{1 0}^{-\mathbf{8}}\right)$ or for any of the other eight combinations of lung function and air pollution measures. For the six SNPs which were highly probable to be causal drivers of their respective signals (posterior probability $>0.9$ ), none showed any evidence of any chromatin effects using DeepSEA (Supplementary table 7).

\section{Effects of Socio-Economic Status}

When adjusting for socio-economic status variables educational status and income status, sample sizes were reduced to 259,130 and 240,202 for the $\mathrm{NO}_{2}$ and $\mathrm{PM}_{10} / \mathrm{PM}_{2.5}$ analyses respectively. Effect sizes were largely consistent with the primary analysis with minimal reductions in effect size for rs74048016 and rs192415220 (Supplementary table 8 and Supplementary figure 7), suggesting that the interactions identified were not due to confounding by SES factors. Interaction effects were generally larger in magnitude (but not significantly due to overlapping confidence intervals) for those in the lower educational group (Supplementary figure 8). When stratifying by income group 
medRxiv preprint doi: https://doi.org/10.1101/2021.06.03.21256376; this version posted June 7, 2021. The copyright holder for this preprint (which was not certified by peer review) is the author/funder, who has granted medRxiv a license to display the preprint in perpetuity. It is made available under a CC-BY 4.0 International license.

(Supplementary figure 9), overlapping confidence intervals again suggested no significant effect of income status on air pollution and lung function association across genotype groups. A slight inverse correlation between magnitude of interaction effect and income group was observed for rs 2825255 for both lung function traits (higher income group, smaller interaction effect magnitude) with a positive correlation observed for rs762101031 (higher income group, larger interaction effect magnitude).

\section{Lung function associated signals}

To determine whether any signals previously shown to be associated with lung function produced an interaction effect with air pollution variables, we performed a look up of the 304 variants (279 lung function signals from Shrine et al. (6) and 24 COPD signals from Sakornsakolpat et al. (5)) in our genome-wide analysis. Of the 304 signals, one signal, rs10841302, near AEBP2, for which the $\mathrm{G}$ allele is associated with lower values of $F E V_{1} / F V C$, met a Bonferroni threshold of $\mathrm{P}<1.6 \times 10^{-4}$ for an interaction with $\mathrm{PM}_{2.5}$ for $\mathrm{FEV}_{1} / \mathrm{FVC}$ (interaction $\beta$ : -0.0118; $\mathrm{Cl}$ : -0.0170,-0.0066; interaction $P=9.65 \times 10^{-6}$ ) (Supplementary table 9), suggesting a larger deleterious effect of $\mathrm{PM}_{2.5}$ on $\mathrm{FEV} / \mathrm{FVC}$ as copies of the $\mathrm{G}$ allele increased (Figure 3). This is equivalent to an $\mathrm{FEV}_{1} / \mathrm{FVC}$ effect of -0.073 percentage points ( $\mathrm{Cl}$ : $-0.105,-0.041)$ per unit increase in $\mathrm{PM}_{2.5}$. The interaction can also be interpreted by air pollution and lung function association stratified by genotype group. For genotype groups CC, CG and GG for SNP rs10841302, a unit increase in $\mathrm{PM}_{2.5}\left(1 \mu \mathrm{g} / \mathrm{m}^{3}\right)$ resulted in a reduction of $\mathrm{FEV}_{1} / \mathrm{FVC}$ by 0.032 (95\% Cl: $\left.0.026-0.038 ; \mathrm{P}=1.21 \times 10^{-22}\right)$, $0.034(95 \% \mathrm{Cl}: 0.028-0.040 ; \mathrm{P}=$ $\left.5.52 \times 10^{-39}\right)$ and $0.056\left(95 \% \mathrm{Cl}: 0.048-0.064 ; \mathrm{P}=2.43 \times 10^{-43}\right)$ standard deviations. This equates to direct $\mathrm{FEV}_{1} / \mathrm{FVC}$ effects of 0.19 ( $\left.95 \% \mathrm{Cl}: 0.16-0.23\right), 0.20$ (95\% Cl: $\left.0.17-0.24\right)$ and $0.33(95 \% \mathrm{Cl}$ : $0.29-0.38$ ) percentage points respectively per $1 \mu \mathrm{g} / \mathrm{m}^{3}$ of $\mathrm{PM}_{2.5}$.

We tested the interaction between a weighted polygenic risk score for lung function (based on the effect sizes of 279 lung function signals reported in Shrine et al. (6)) and each air pollution measure on $\mathrm{FEV}_{1}, \mathrm{FVC}$ and $\mathrm{FEV}_{1} / \mathrm{FVC}$ (Supplementary table 10). None of the interaction effects were statistically significant (all $P>0.05$ ).

\section{Antioxidant genes and their interaction with air pollution}

We performed a look up of the 13 variants corresponding to seven commonly evaluated antioxidant genes and/or those analysed in previous studies of antioxidant gene-air pollution interaction analyses, as reviewed by Fuertes et al. (25) (Supplementary table 11). None of the SNPs reached the Bonferroni significant adjusted threshold used to determine statistical significance $(P<3.85 \times$ $\left.10^{-3}\right)$. One SNP, rs1001179 in CAT approached this threshold $(\mathrm{P}=0.009)$ for an interaction with $\mathrm{NO}_{2}$ for lung function phenotype $\mathrm{FEV}_{1} / \mathrm{FVC}$. 
medRxiv preprint doi: https://doi.org/10.1101/2021.06.03.21256376; this version posted June 7, 2021. The copyright holder for this preprint (which was not certified by peer review) is the author/funder, who has granted medRxiv a license to display the preprint in perpetuity.

It is made available under a CC-BY 4.0 International license .

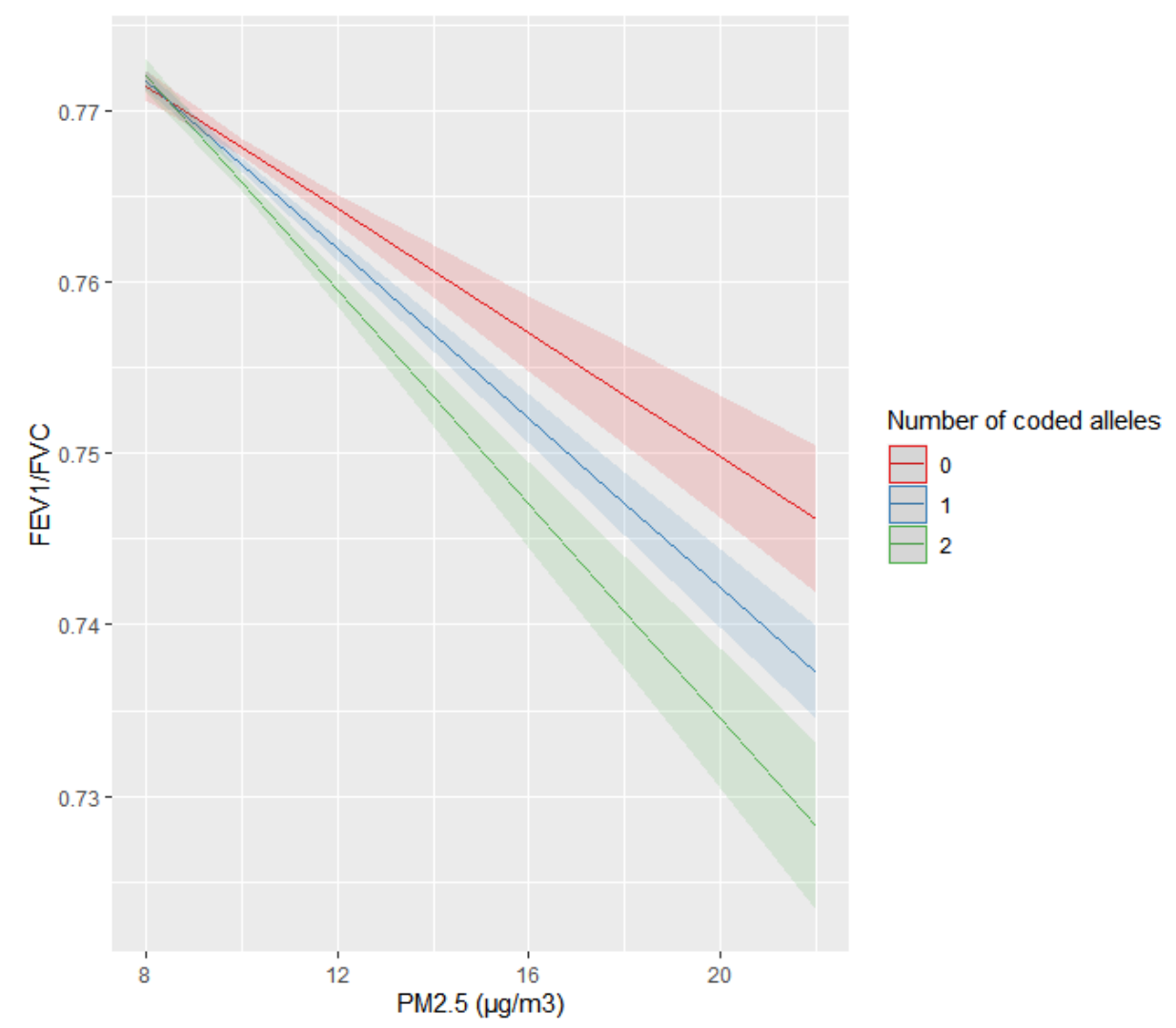

Figure 3 - Interaction plot of FEV 1 /FVC predicted values against $P M_{2.5}$ values across genotype groups (with coded allele $G$ ) for the previously identified lung function signal rs 10841302

\section{Discussion}

We carried out the largest genome-wide gene-air pollution interaction study of lung function and identified seven genome-wide statistically significant signals, as well as identifying an interaction with air pollution for one previously identified lung function signal.

For the signals identified, ascribing the biological mechanisms proves a challenge and further biological studies of gene function for those implicated are needed. For genome-wide SNP rs74048016, as the number of copies of the coded allele increases the effect of air pollutant $\mathrm{PM}_{10}$ on FVC becomes more negative, suggesting that those with two copies of the effect allele are at increased susceptibility of air pollution effects. The coded allele is associated with decreased expression of HES4 and increased expression of C1orf159 in blood in Open Targets Genetics. The signals for genome-wide association and gene expression signals did not colocalise (there was insufficient evidence of a shared causal variant between the two analyses) in this genomic region (using data from eQTLgen). Expression of HES4 (hes family bHLH transcription factor 4) has been implicated in poor outcomes for patients with Triple Negative Breast Cancer (TNBC) (26) and both HES4 and C1orf159 (chromosome 1 open reading frame 159) have been implicated via functional annotation (nearest gene) of other genome-wide significant loci for several traits and diseases, including peak expiratory flow (PEF) $(27,28)$. There is also evidence of colocalisation between gene expression and genome-wide analyses for these genes in certain tissues for height phenotypes (standing and sitting) $(27,28)$. 
medRxiv preprint doi: https://doi.org/10.1101/2021.06.03.21256376; this version posted June 7, 2021. The copyright holder for this preprint (which was not certified by peer review) is the author/funder, who has granted medRxiv a license to display the preprint in perpetuity. It is made available under a CC-BY 4.0 International license .

We identified a further ten signals (independent of the primary genome-wide signals) at suggestive statistical significance, which would be important to take forward in future replication analyses. Genes implicated include PNMA2, DPYSL2 and BNIP3L, all via functional annotation of other genome-wide significant loci for height, and additionally for educational attainment phenotypes (29, 30). There was however no attenuation of suggestive signal rs139556451 (which implicated the aforementioned genes in our analysis) when re-analysing with adjustment for education and income status (in the subset for which this data was available). BNIP3L expression has also been linked with lung cancer (31). Additionally, gene FRAS1 identified by eQTL associations for SNPs in the rs111552599 suggestive signal credible set has been implicated by other genome-wide signals for lung function, specifically for trait $\operatorname{FEV}_{1} / \operatorname{FVC}(6,29)$ and mutations in $F R A S 1$ have been observed amongst individuals with Fraser syndrome, which can cause airway abnormalities $(32,33)$. MUC4 (identified by credible set eQTL associations for rs200460259), which encodes airway mucins (34) is associated with severity of lung disease in cystic fibrosis (through functional annotation of another genome-wide signal) (35) and risk of lung cancer (association with variants in the gene) (36). We were however unable to determine whether the association signal for the genes described here were driven by the same causal variant as the interaction signal.

We identified an interaction effect between SNP rs10841302 (a previously identified lung function signal associated with $\mathrm{FEV}_{1} / \mathrm{FVC}$ ) and $\mathrm{PM}_{2.5}$ for lung function trait $\mathrm{FEV}_{1} / \mathrm{FVC}$. Previous work has shown that the rs $10841302 \mathrm{G}$-allele is associated with a deleterious effect on $\mathrm{FEV}_{1} / \mathrm{FVC}$. We found that this deleterious effect increased in magnitude as the exposure to $\mathrm{PM}_{2.5}$ increased. A causative gene for the association between rs10841302 and lung function has not been determined. The SNP is near AEBP2 (AE Binding Protein 2), a transcriptional repressor with a possible contribution to histone methylation and the $\mathrm{G}$ allele is associated with increased expression of both RP11-405A12.2 (in pancreas and subcutaneous adipose tissues) and RP11-664H17.1 (in pancreas and tibial nerve tissues) in GTEx (17). There was no evidence of an interaction between air pollution measures and a combined effect from all previously identified lung function signals represented by a polygenic risk score.

A particular strength of this study is the discovery sample size available for the interaction analysis. Interactions are challenging to identify due to the requirement of much larger sample sizes than GWAS efforts exploring the marginal effects of genetic variants (37). This strength is however unfortunately a contributor to its biggest limitation, which is identifying suitable independent datasets of sufficient sample size with lung function data in European ancestry populations to replicate discovery interaction signals. We calculated that sample sizes to replicate three of our novel genome-wide interaction signals when considering the reported interaction effect, main genetic effect and air pollution variable effect (chosen from each MAF frequency group of common, low frequency and rare), signals rs28666788 (MAF $=10 \%), r s 74048016$ (MAF $=2 \%$ ) and rs192415220 (MAF $=0.6 \%$ ) would be $\sim 72 \mathrm{k}, \sim 71 \mathrm{k}$ and $\sim 66 \mathrm{k}$ respectively to detect the effect at $80 \%$ power. However, these sample sizes are indeed sensitive to any observed error in interaction effect estimates, such that when using lower and upper confidence interval effect estimates, sample sizes required could range from $\sim 35 k$ to $\sim 194 k$.

The discovery of gene-air pollution interactions which affect lung function susceptibility is limited, likely due to the aforementioned difficulty in identifying suitable sample sizes to provide adequate power. Previous genome-wide interaction studies are either attributed to related phenotypes, such as asthma (38) or have focussed on candidate genes, such as those with a role in oxidative stress, where conclusions drawn are often inconsistent with respect to direction of effect or presence of 
medRxiv preprint doi: https://doi.org/10.1101/2021.06.03.21256376; this version posted June 7, 2021. The copyright holder for this preprint (which was not certified by peer review) is the author/funder, who has granted medRxiv a license to display the preprint in perpetuity. It is made available under a CC-BY 4.0 International license .

interaction $(39,40)$. Previous studies of interactions between genes and smoking behaviour, the largest risk factor for poor lung function and COPD, have also been largely unsuccessful in identifying interaction signals. This has been of interest as not all smokers develop restrictive lung problems. Candidate gene-smoking interactions have been identified, however utilising small sample sizes with absence of replication (41-43) and none of the previously identified lung function signals produced an interaction with smoking behaviour (6). Genome-wide interaction analysis efforts have also been considered for lung function (44) however with little success, and although a recent study of genesmoking interaction effects for COPD found a genome-wide significant interaction at 15q25.1 (45), this is likely driven by the strong association between this locus and smoking behaviour (46-48). There has however been some evidence of interaction between smoking behaviour and genetic risk scores, when combining the effects of SNPs associated with lung function $(6,49)$. To the best of our knowledge, no genome-wide significant smoking interaction signals for lung function have been identified, highlighting the impact of identifying novel genome-wide gene-air pollution interaction signals.

Should the interaction effects be replicated in future analyses, the magnitude of effects observed here suggest potential for clinically relevant impacts on those with certain genotypes. Results (Table 1, Figure 2) are expressed per unit pollutant. For context, average annual concentrations of $\mathrm{PM}_{10}$ in 2018 were $14.7 \mu \mathrm{g} / \mathrm{m}^{3}$ in 2018 at urban background air quality monitoring sites (likely to represent where most of the UK population live) (50). Corresponding concentrations for $\mathrm{PM}_{2.5}$ and $\mathrm{NO}_{2}$ was $10.0 \mathrm{\mu g} / \mathrm{m}^{3}$ and $20.1 \mathrm{\mu g} / \mathrm{m}^{3}$ respectively. Taking genome-wide signal rs28666788 as an example, (with coded allele $\mathrm{G}$ frequency of 0.096 ), effects on $\mathrm{FEV}_{1}$ per unit increase in $\mathrm{PM}_{10}$ were statistically significant for all genotype groups. For those with zero, one and two copies of the effect allele, lung function effects of approximately $-7.5 \mathrm{ml},-17.5 \mathrm{ml}$ and $-30 \mathrm{ml}$ were observed per $1 \mu \mathrm{g} / \mathrm{m}^{3} \mathrm{PM}_{10}$ respectively (figure 2). Therefore, when subjected to the average concentrations of $14.7 \mu \mathrm{g} / \mathrm{m}^{3}$ of $\mathrm{PM}_{10}$, this equates to respective reductions of $112.5 \mathrm{ml}, 260 \mathrm{ml}$ and $440 \mathrm{ml}$. Average declines in $\mathrm{FEV}_{1}$ per year could be up to $46 \mathrm{ml}$ for individuals aged 30 onwards (51), so these effects are approximately equivalent to nine years of normal loss of lung function for those with two copies of the coded allele (4 and 7 more than those with one and zero copies respectively). For other SNPs, such as rs 2825255 , with coded allele $(T)$ frequency of 0.83 , association between lung function and air pollutant is observed for certain genotype groups. Using the average $\mathrm{NO}_{2}$ measure, those with one and two copies of the effect allele could be subject to reductions in $\mathrm{FEV}_{1}$ of approximately $35 \mathrm{ml}$ and $75 \mathrm{ml}$ (approximately equivalent to 0.75 and 1.5 years of normal lung function decline respectively), as opposed to those with zero copies, where there was no observed statistically significant effect of air pollutant on $\mathrm{FEV}_{1}$ (confidence interval overlaps 0 ).

There were approximately 40,000 individuals with clean lung function data with missing data for education and income status. We expect that those with higher SES and higher income are more likely to have complete data thus the data is not missing at random. We did not carry out imputation as it is difficult to know which might introduce more bias, imputation or exclusion and thus carried out a complete-case analysis. Further studies are required in this respect. Previous studies have reported modification of air pollution effects on lung function when considering SES (4, 52-54) possibly due to differences in housing conditions, indoor air quality, nutrition and occupation (54). Adjusting for SES and presenting interaction effects across educational and income groups did not produce a notable modification of interaction effects in our analyses, suggesting that observed differences in the effect of air pollution across genotype groups are not mediated or confounded by socio-economic status. 
medRxiv preprint doi: https://doi.org/10.1101/2021.06.03.21256376; this version posted June 7, 2021. The copyright holder for this preprint (which was not certified by peer review) is the author/funder, who has granted medRxiv a license to display the preprint in perpetuity.

It is made available under a CC-BY 4.0 International license .

There are other limitations with this study. We only had air pollution data at baseline with some limitations in the availability and did not have follow-up data. An analysis of a German cohort of 601 elderly women (mainly non-smokers) with three follow-ups from 1985-2013 suggested that changes in air pollution over time was associated with improvements in lung function, modified by genetic factors (55). In addition, there are limitations with the ESCAPE models $(8,9)$. Exposure estimates are based on place of residence so will not capture variability in exposure related to work and leisure activities outside the home, which may have led to exposure misclassification bias making it harder to detect effects. Furthermore, it must be noted that our analysis includes imputed genetic dosages alongside directly genotyped data and we only considered an additive genetic model for our analysis. Previous studies for certain antioxidant gene SNPs such as rs1695 in GSTP1 have also considered the suitability of alternative genetic models $(56,57)$.

\section{Conclusions}

We have identified genetic variants whose effect on lung function is dependent on air pollution exposure levels. This could help identify high-risk genetic subgroups whose lung function could be more susceptible to the effects of outdoor air pollution. While this is the largest study of this type to date, we highlight the need for replication in independent datasets with recorded lung function, for which availability is currently limited. We hope that future replication and further biological studies of gene function will help to establish the genes and biological pathways involved. 
medRxiv preprint doi: https://doi.org/10.1101/2021.06.03.21256376; this version posted June 7, 2021. The copyright holder for this preprint (which was not certified by peer review) is the author/funder, who has granted medRxiv a license to display the preprint in perpetuity.

It is made available under a CC-BY 4.0 International license .

\section{References}

1. GBD 2016 Causes of Death Collaborators. Global, regional, and national age-sex specific mortality for 264 causes of death, 1980-2016: a systematic analysis for the Global Burden of Disease Study 2016. Lancet. 2017 Sep 16;390(10100):1151-210.

2. Rabe KF, Watz H. Chronic obstructive pulmonary disease. Lancet. 2017 May 13;389(10082):193140.

3. Agustí A, Hogg JC. Update on the Pathogenesis of Chronic Obstructive Pulmonary Disease. N Engl J Med. 2019 Sep 26;381(13):1248-56.

4. Doiron D, de Hoogh K, Probst-Hensch N, Fortier I, Cai Y, De Matteis S, et al. Air pollution, lung function and COPD: results from the population-based UK Biobank study. Eur Respir J. 2019 Jul 25;54(1):1802140. doi: 10.1183/13993003.02140,2018. Print 2019 Jul.

5. Sakornsakolpat P, Prokopenko D, Lamontagne M, Reeve NF, Guyatt AL, Jackson VE, et al. Genetic landscape of chronic obstructive pulmonary disease identifies heterogeneous cell-type and phenotype associations. Nat Genet. 2019 Mar;51(3):494-505.

6. Shrine N, Guyatt AL, Erzurumluoglu AM, Jackson VE, Hobbs BD, Melbourne CA, et al. New genetic signals for lung function highlight pathways and chronic obstructive pulmonary disease associations across multiple ancestries. Nat Genet. 2019 Mar;51(3):481-93.

7. Manichaikul A, Mychaleckyj JC, Rich SS, Daly K, Sale M, Chen WM. Robust relationship inference in genome-wide association studies. Bioinformatics. 2010 Nov 15;26(22):2867-73.

8. Eeftens M, Beelen R, de Hoogh K, Bellander T, Cesaroni G, Cirach M, et al. Development of Land Use Regression models for PM(2.5), PM(2.5) absorbance, PM(10) and PM(coarse) in 20 European study areas; results of the ESCAPE project. Environ Sci Technol. 2012 Oct 16;46(20):11195-205.

9. Beelen R, Hoek G, Vienneau D, Eeftens M, Dimakopoulou K, Pedeli X, et al. Development of NO2 and NOx land use regression models for estimating air pollution exposure in 36 study areas in Europe - The ESCAPE project. Atmos Environ. 2013;72:10-23.

10. Bycroft C, Freeman C, Petkova D, Band G, Elliott LT, Sharp K, et al. The UK Biobank resource with deep phenotyping and genomic data. Nature. 2018 Oct;562(7726):203-9.

11. McCarthy S, Das S, Kretzschmar W, Delaneau O, Wood AR, Teumer A, et al. A reference panel of 64,976 haplotypes for genotype imputation. Nat Genet. 2016 Oct;48(10):1279-83.

12. Huang J, Howie B, McCarthy S, Memari Y, Walter K, Min JL, et al. Improved imputation of lowfrequency and rare variants using the UK10K haplotype reference panel. Nat Commun. 2015 Sep $14 ; 6: 8111$.

13. Chang CC, Chow CC, Tellier LC, Vattikuti S, Purcell SM, Lee JJ. Second-generation PLINK: rising to the challenge of larger and richer datasets. Gigascience. 2015 Feb 25;4:7,8. eCollection 2015.

14. Pruim RJ, Welch RP, Sanna S, Teslovich TM, Chines PS, Gliedt TP, et al. LocusZoom: regional visualization of genome-wide association scan results. Bioinformatics. 2010 Sep 15;26(18):2336-7. 
medRxiv preprint doi: https://doi.org/10.1101/2021.06.03.21256376; this version posted June 7, 2021. The copyright holder for this preprint (which was not certified by peer review) is the author/funder, who has granted medRxiv a license to display the preprint in perpetuity.

It is made available under a CC-BY 4.0 International license .

15. Wakefield J. A Bayesian measure of the probability of false discovery in genetic epidemiology studies. Am J Hum Genet. 2007 Aug;81(2):208-27.

16. Wang K, Li M, Hakonarson $\mathrm{H}$. ANNOVAR: functional annotation of genetic variants from highthroughput sequencing data. Nucleic Acids Res. 2010 Sep;38(16):e164.

17. The Genotype-Tissue Expression (GTEx) project. Nat Genet. 2013 -06;45(6):580-5.

18. Westra H, Peters MJ, Esko T, Yaghootkar H, Schurmann C, Kettunen J, et al. Systematic identification of trans eQTLs as putative drivers of known disease associations. Nat Genet. 2013 10;45(10):1238-43.

19. Giambartolomei C, Vukcevic D, Schadt EE, Franke L, Hingorani AD, Wallace C, et al. Bayesian test for colocalisation between pairs of genetic association studies using summary statistics. PLoS Genet. $2014-05 ; 10(5): e 1004383$.

20. U V, A C, H W, Mj B, P D, B Z, et al. Unraveling the polygenic architecture of complex traits using blood eQTL metaanalysis. . 2018/10/19.

21. Ghoussaini M, Mountjoy E, Carmona M, Peat G, Schmidt EM, Hercules A, et al. Open Targets Genetics: systematic identification of trait-associated genes using large-scale genetics and functional genomics. Nucleic Acids Res. 2021 -01-08;49(D1):D1311-20.

22. Staley JR, Blackshaw J, Kamat MA, Ellis S, Surendran P, Sun BB, et al. PhenoScanner: a database of human genotype-phenotype associations. Bioinformatics. 2016 -10-15;32(20):3207-9.

23. lotchkova V, Ritchie GRS, Geihs M, Morganella S, Min JL, Walter K, et al. GARFIELD classifies disease-relevant genomic features through integration of functional annotations with association signals. Nat Genet. 2019 -02;51(2):343-53.

24. Zhou J, Troyanskaya OG. Predicting effects of noncoding variants with deep learning-based sequence model. Nat Methods. 2015 -10;12(10):931-4.

25. Fuertes E, van der Plaat, Diana A., Minelli C. Antioxidant genes and susceptibility to air pollution for respiratory and cardiovascular health. Free Radic Biol Med. 2020 -05-01;151:88-98.

26. Stoeck A, Lejnine S, Truong A, Pan L, Wang H, Zang C, et al. Discovery of biomarkers predictive of GSI response in triple negative breast cancer and adenoid cystic carcinoma. Cancer Discov. 2014 10;4(10):1154-67.

27. Ghoussaini M, Mountjoy E, Carmona M, Peat G, Schmidt EM, Hercules A, et al. Open Targets Genetics: systematic identification of trait-associated genes using large-scale genetics and functional genomics. Nucleic Acids Res. 2021 -01-08;49(D1):D1311-20.

28. UK Biobank [Internet]. [cited Feb 17, 2021]. Available from: http://www.nealelab.is/uk-biobank.

29. Kichaev G, Bhatia G, Loh P, Gazal S, Burch K, Freund MK, et al. Leveraging Polygenic Functional Enrichment to Improve GWAS Power. Am J Hum Genet. 2019 -01-03;104(1):65-75. 
medRxiv preprint doi: https://doi.org/10.1101/2021.06.03.21256376; this version posted June 7, 2021. The copyright holder for this preprint (which was not certified by peer review) is the author/funder, who has granted medRxiv a license to display the preprint in perpetuity.

It is made available under a CC-BY 4.0 International license.

30. Lee JJ, Wedow R, Okbay A, Kong E, Maghzian O, Zacher M, et al. Gene discovery and polygenic prediction from a genome-wide association study of educational attainment in 1.1 million individuals. Nat Genet. 2018 -07-23;50(8):1112-21.

31. Sun J, He X, Yu Y, Chen Z. [Expression and structure of BNIP3L in lung cancer]. Ai Zheng. 2004 01;23(1):8-14.

32. Pitera JE, Scambler PJ, Woolf AS. Fras1, a basement membrane-associated protein mutated in Fraser syndrome, mediates both the initiation of the mammalian kidney and the integrity of renal glomeruli. Hum Mol Genet. 2008 -12-15;17(24):3953-64.

33. van Haelst MM, Scambler PJ, Hennekam RCM. Fraser syndrome: a clinical study of 59 cases and evaluation of diagnostic criteria. Am J Med Genet A. 2007 -12-15;143A(24):3194-203.

34. Copin MC, Devisme L, Buisine MP, Marquette CH, Wurtz A, Aubert JP, et al. From normal respiratory mucosa to epidermoid carcinoma: expression of human mucin genes. Int J Cancer. 2000 04-15;86(2):162-8.

35. Corvol H, Blackman SM, Boëlle P, Gallins PJ, Pace RG, Stonebraker JR, et al. Genome-wide association meta-analysis identifies five modifier loci of lung disease severity in cystic fibrosis. Nat Commun. 2015 -09-29;6:8382.

36. Zhang Z, Wang J, He J, Zheng Z, Zeng X, Zhang C, et al. Genetic variants in MUC4 gene are associated with lung cancer risk in a Chinese population. PLoS One. 2013;8(10):e77723.

37. Thomas D. Gene--environment-wide association studies: emerging approaches. Nat Rev Genet. $2010-04 ; 11(4): 259-72$.

38. Gref A, Merid SK, Gruzieva O, Ballereau S, Becker A, Bellander T, et al. Genome-Wide Interaction Analysis of Air Pollution Exposure and Childhood Asthma with Functional Follow-up. Am J Respir Crit Care Med. 2017 -05-15;195(10):1373-83.

39. Minelli C, Wei I, Sagoo G, Jarvis D, Shaheen S, Burney P. Interactive effects of antioxidant genes and air pollution on respiratory function and airway disease: a HuGE review. Am J Epidemiol. 2011 03-15;173(6):603-20.

40. Romieu I, Moreno-Macias H, London SJ. Gene by environment interaction and ambient air pollution. Proc Am Thorac Soc. 2010 -05;7(2):116-22.

41. Sadeghnejad A, Meyers DA, Bottai M, Sterling DA, Bleecker ER, Ohar JA. IL13 promoter polymorphism 1112C/T modulates the adverse effect of tobacco smoking on lung function. Am J Respir Crit Care Med. 2007 -10-15;176(8):748-52.

42. Hunninghake GM, Cho MH, Tesfaigzi Y, Soto-Quiros ME, Avila L, Lasky-Su J, et al. MMP12, lung function, and COPD in high-risk populations. N Engl J Med. 2009 -12-31;361(27):2599-608.

43. He J, Connett JE, Anthonisen NR, Paré PD, Sandford AJ. Glutathione S-transferase variants and their interaction with smoking on lung function. Am J Respir Crit Care Med. 2004 -08-15;170(4):38894. 
medRxiv preprint doi: https://doi.org/10.1101/2021.06.03.21256376; this version posted June 7, 2021. The copyright holder for this preprint (which was not certified by peer review) is the author/funder, who has granted medRxiv a license to display the preprint in perpetuity. It is made available under a CC-BY 4.0 International license .

44. Hancock DB, Soler Artigas M, Gharib SA, Henry A, Manichaikul A, Ramasamy A, et al. Genomewide joint meta-analysis of SNP and SNP-by-smoking interaction identifies novel loci for pulmonary function. PLoS Genet. 2012;8(12):e1003098.

45. Kim W, Prokopenko D, Sakornsakolpat P, Hobbs BD, Lutz SM, Hokanson JE, et al. Genome-wide Gene-by-smoking Interaction Study of Chronic Obstructive Pulmonary Disease. American Journal of Epidemiology. 2020 October 27,(kwaa227).

46. Thorgeirsson TE, Gudbjartsson DF, Surakka I, Vink JM, Amin N, Geller F, et al. Sequence variants at CHRNB3-CHRNA6 and CYP2A6 affect smoking behavior. Nat Genet. 2010 -05;42(5):448-53.

47. Liu JZ, Tozzi F, Waterworth DM, Pillai SG, Muglia P, Middleton L, et al. Meta-analysis and imputation refines the association of 15q25 with smoking quantity. Nat Genet. $2010-05 ; 42(5): 436-$ 40.

48. Genome-wide meta-analyses identify multiple loci associated with smoking behavior. Nat Genet. $2010-05 ; 42(5): 441-7$.

49. Aschard H, Tobin MD, Hancock DB, Skurnik D, Sood A, James A, et al. Evidence for large-scale gene-by-smoking interaction effects on pulmonary function. Int J Epidemiol. 2017 -06-01;46(3):894904.

50. Air quality statistics GOV.UK [Internet]. [cited 22/02/21].

51. Quanjer PH, Stanojevic S, Cole TJ, Baur X, Hall GL, Culver BH, et al. Multi-ethnic reference values for spirometry for the 3-95-yr age range: the global lung function 2012 equations. Eur Respir J. 2012 $-12 ; 40(6): 1324-43$.

52. Doiron D, de Hoogh K, Probst-Hensch N, Mbatchou S, Eeftens M, Cai Y, et al. Residential Air Pollution and Associations with Wheeze and Shortness of Breath in Adults: A Combined Analysis of Cross-Sectional Data from Two Large European Cohorts. Environ Health Perspect. 2017 -0929;125(9):097025.

53. Wheeler BW, Ben-Shlomo Y. Environmental equity, air quality, socioeconomic status, and respiratory health: a linkage analysis of routine data from the Health Survey for England. J Epidemiol Community Health. 2005 -11;59(11):948-54.

54. Forastiere F, Stafoggia M, Tasco C, Picciotto S, Agabiti N, Cesaroni G, et al. Socioeconomic status, particulate air pollution, and daily mortality: differential exposure or differential susceptibility. Am J Ind Med. 2007 -03;50(3):208-16.

55. Hüls A, Sugiri D, Abramson MJ, Hoffmann B, Schwender H, Ickstadt K, et al. Benefits of improved air quality on ageing lungs: impacts of genetics and obesity. Eur Respir J. 2019 -04;53(4).

56. Wang S, Zhang J, Jun F, Bai Z. Glutathione S-transferase pi 1 variant and squamous cell carcinoma susceptibility: a meta-analysis of 52 case-control studies. BMC Med Genet. 2019 -01-21;20(1):22.

57. Song Z, Shao C, Feng C, Lu Y, Gao Y, Dong C. Association of glutathione S-transferase T1, M1, and P1 polymorphisms in the breast cancer risk: a meta-analysis. Ther Clin Risk Manag. 2016;12:763-9. 
medRxiv preprint doi: https://doi.org/10.1101/2021.06.03.21256376; this version posted June 7, 2021. The copyright holder for this preprint (which was not certified by peer review) is the author/funder, who has granted medRxiv a license to display the preprint in perpetuity.

It is made available under a CC-BY 4.0 International license .

\section{Funding and acknowledgements}

Louise Wain holds a GSK/British Lung Foundation Chair in Respiratory Research (C17-1). The research was partially supported by the National Institute for Health Research (NIHR) Leicester Biomedical Research Centre; the views expressed are those of the author(s) and not necessarily those of the National Health Service (NHS), the NIHR or the Department of Health.

Martin Tobin is supported by a Wellcome Trust Investigator Award (WT202849/Z/16/Z) and holds an NIHR Senior Investigator Award.

Anna Hansell acknowledges funding from the Health Protection Research Unit in Environmental Exposures and Health, a partnership between Public Health England, the Health and Safety Executive and the University of Leicester. The views expressed are those of the authors and not necessarily those of the NHS the NIHR, Public Health England, the Health and Safety Executive or the Department of Health and Social Care.

The analysis was undertaken using UK Biobank data application 648.

This research used the High Performance Computing facilities at the University of Leicester (ALICE and SPECTRE).

\section{Competing interests}

Martin Tobin and Louise Wain have research collaborations with GSK and with Orion Pharma unrelated to this paper. 